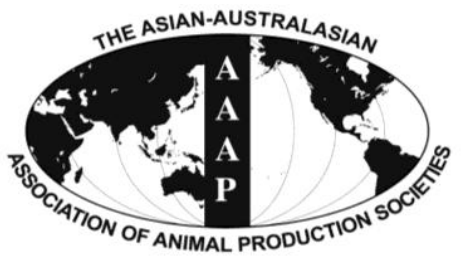

Asian-Aust. J. Anim. Sci.

Vol. 26, No. 1 : 143-150 January 2013

http://dx.doi.org/10.5713/ajas.2012.12431

www.ajas.info

pISSN 1011-2367 elSSN 1976-5517

\title{
Preliminary Evaluation of Slaughter Value and Carcass Composition of Indigenous Sheep and Goats from Traditional Production System in Tanzania
}

\author{
Dismas S. Shija*, Louis A. Mtenga, Abiliza E. Kimambo, Germana H. Laswai, Daniel E. Mushi, \\ Dynes M. Mgheni, Angello J. Mwilawa ${ }^{1}$, Eligy J. M. Shirima ${ }^{2}$ and John G. Safari ${ }^{3}$ \\ Sokoine University of Agriculture, Department of Animal Science and Production, \\ P.O. Box 3004, Morogoro, Tanzania
}

\begin{abstract}
The aim of the pilot study was to evaluate slaughter characteristics and carcass composition of indigenous long fat tailed sheep and Small East African goats purchased from the auction markets slaughtered at 1.5 to 2 yrs of age and $20 \mathrm{~kg}$ to $25 \mathrm{~kg}$ live weight. The animals were slaughtered according to halal standard procedures. The left half carcasses were jointed into eight wholesale joints, and dissected into muscles, fat and bone, which were weighed separately. Sheep had greater $(\mathrm{p}<0.05)$ slaughter BW $(22.29 \mathrm{~kg}$ vs 20.50 $\mathrm{kg})$ and empty BW (20.17 kg vs $18.67 \mathrm{~kg})$ than goats $(\mathrm{p}<0.05)$. Dressing percentages were lower $(\mathrm{p}<0.001)$ in sheep than goats when carcass weight was expressed as percentage of slaughter BW $(42.31 \%$ and $47.15 \%)$ and empty BW (46.75\% and 51.79\%). Sheep carcasses had lower $(\mathrm{p}<0.001)$ proportion $(66.18 \%$ vs $71.64 \%)$ of muscles and higher $(\mathrm{p}<0.001)$ proportion of fat $(7.41 \%$ vs $3.44 \%)$ than goat carcasses. Sheep had proportionally lighter $(\mathrm{p}<0.001)$ shoulder $(18.89 \%$ vs $22.68 \%)$ and heavier $(\mathrm{p}<0.05)$ proportion of chump $(7.916 \%$ vs $6.76 \%)$ and main rib $(8.12 \%$ vs $7.07 \%)$. Sheep had more $(\mathrm{p}<0.001)$ muscles in the leg $(28.83 \%$ vs $27.08 \%)$ and main rib $(7.62 \%$ vs $6.36 \%)$ than goats. Sheep had less $(\mathrm{p}<0.001)$ muscles $(20.28 \%$ vs $23.56 \%)$ in shoulder joints when expressed as percentage of total muscle of carcasses. It is concluded that there are differences in sheep and goat both in terms of carcass and joint yields and composition. The present study also implies that there is need to consider setting different meat cuts and prices for these cuts when one takes into account the differences in muscle distribution within joints in sheep and goats. (Key Words: Carcass Composition, Dressing Percent, Goat, Sheep, Slaughter Characteristics)
\end{abstract}

\section{INTRODUCTION}

Sheep and goats constitute the majority of the ruminant population in developing countries (Titi et al., 2008) and contribute significantly to household economy. In Tanzania, sheep and goats are mainly kept under the traditional grazing system with low feed inputs (Hango et al., 2007) and contribute about 22 percent of the national red meat supplies (Msanga, 2009). Under such a system, which is

\footnotetext{
* Corresponding Author: Dismas S. Shija. Tel: +255-757144700, Fax: +255-232604562, E-mail: shija78@gmail.com

${ }^{1}$ National Livestock Research Institute, P.O. Box 202, Mpwapwa, Tanzania.

${ }^{2}$ Ministry of Livestock Development and Fisheries, P. O. Box 9152, Dar es Salaam, Tanzania.

${ }^{3}$ Institute of Rural Development and Planning, P.O. Box 138, Dodoma, Tanzania.

Submitted Aug. 10, 2012; Accepted Sept. 10, 2012; Revised Sept. 18, 2012
}

also found in most of the Sub Sahara region (El Khidir et al., 1998), animals grow slowly and are slaughtered at an older age. Several studies conducted under the same slaughter weight, age and or feeding management of sheep and goats have revealed species and breed differences in carcass composition (Miller et al., 2001; Voges et al., 2007; Lee et al., 2008). Berg and Butterfield (1976) with cattle and Mahgoub and Lu (1998) with goats have highlighted the need to consider both physiological and chronological stages of animals at slaughter as these stages are the key factors masking observations on the effects of species and breed on carcass characteristics studies.

Information on carcass composition of sheep and goats from traditional systems are not readily available in SubSaharan Africa. In Tanzania, such information has recently been documented on-station by Mushi et al. (2009) and Safari et al. (2011). Goat meat is characterized by low subcutaneous fat content with greater muscle component at 
comparable age and slaughter live body weight (Babiker et al., 1990). Owen et al. (1978) commented on the difficulties of controlling these masking factors under traditional grazing condition in the tropics. Moreover, information available on station may not be applicable under the traditional system of keeping animals in the tropics. The aim of this study was, therefore, to compare slaughter characteristics and carcass composition of sheep and goats from the traditional livestock production system in Tanzania.

\section{MATERIALS AND METHODS}

\section{Location}

The study was conducted in Dodoma region, central Tanzania, which is located at $6^{\circ} 10^{\prime} 23^{\prime \prime} \mathrm{S} 35^{\circ} 44^{\prime} 31^{\prime \prime} \mathrm{E}$, and $1,120 \mathrm{~m}$ above sea level. The region is a semi-arid climate area with relatively warm temperatures ranging between $16^{\circ} \mathrm{C}$ and $29^{\circ} \mathrm{C}$ and a single rainfall pattern with annual precipitation averaging $70 \mathrm{~mm}$ falling between December and April.

\section{Animals and management}

Thirty-four animals (17 sheep and 17 goats) were bought from livestock auction markets. The animals were purposely selected to include those with live BW ranging from $20 \mathrm{~kg}$ to $25 \mathrm{~kg}$ and age from 1.5 to $2 \mathrm{yrs}$, as these animals are high in demand for exports to Middle East markets. The age of animals was estimated by the pattern of eruption of the incisor teeth (Abegaz and Awgichew, 2009) and only animals with first pair of permanent incisors were sampled. Each selected animal was identified using blue paint before being transported by truck to the Department of Meat Processing Technology (MPT) of Dodoma Regional Vocational Education Training and Services Centre (DRVETSC). The animals were kept in the lairage and fasted for $18 \mathrm{~h}$ with free access to water. Slaughter live BW was taken $16 \mathrm{~h}$ prior to slaughter using a mechanical weighing balance (100 kg, Golden Lark, China).

\section{Slaughtering procedure}

The animals were slaughtered according to standard commercial procedures and bleeding was effected by severing the carotid arteries and jugular vein in a single cut, according to Halal practice. The head was removed at the atlanto-occipital joint and fore and hind feet removed at the carpus-metacarpal and tarsus-metatarsal joints, respectively (Safari et al., 2009; Bonvillani et al., 2010). Carcasses and non-carcasses components were labelled separately for subsequent measurements.

\section{Non-carcass and carcass measurements}

The non-carcass components, which included the head, skin, feet, kidneys, internal fat, testicles, tail, GI tract and pluck (lungs plus trachea, heart, liver and spleen), were weighed and recorded. Gut fill weight was derived as the difference between weights of full and empty GI tract. Carcasses were weighed immediately after dressing the animals to obtain hot carcass weight $(\mathrm{HCW})$. The carcasses were then chilled at $3-4^{\circ} \mathrm{C}$ for a $24 \mathrm{~h}$ period and reweighed to obtain cold carcass weight (CCW). Empty body weight (EBW) was computed as the difference between slaughter weight and weight of gut fill. Dressing percentage was calculated as weight of carcass (hot and cold) divided by either slaughter weight or empty BW times 100 according to Bonvillani et al. (2010) procedures.

\section{Carcass splitting, jointing and dissection}

Carcasses were carefully split longitudinally to obtain left and right halves and weighed. The left half of each carcass was jointed into eight standard commercial joints namely neck, shoulder, breast, loin, chump, main rib, midrib and leg (Figure 1) and dissected into lean, fat and bone.

\section{Statistical analysis}

Data were processed and analysed using the GLM procedures of SAS to determine the influence of species on slaughter characteristics and carcass compositions. The difference between least squares means for sheep and goats were compared by PDIFF (SAS, 2000).

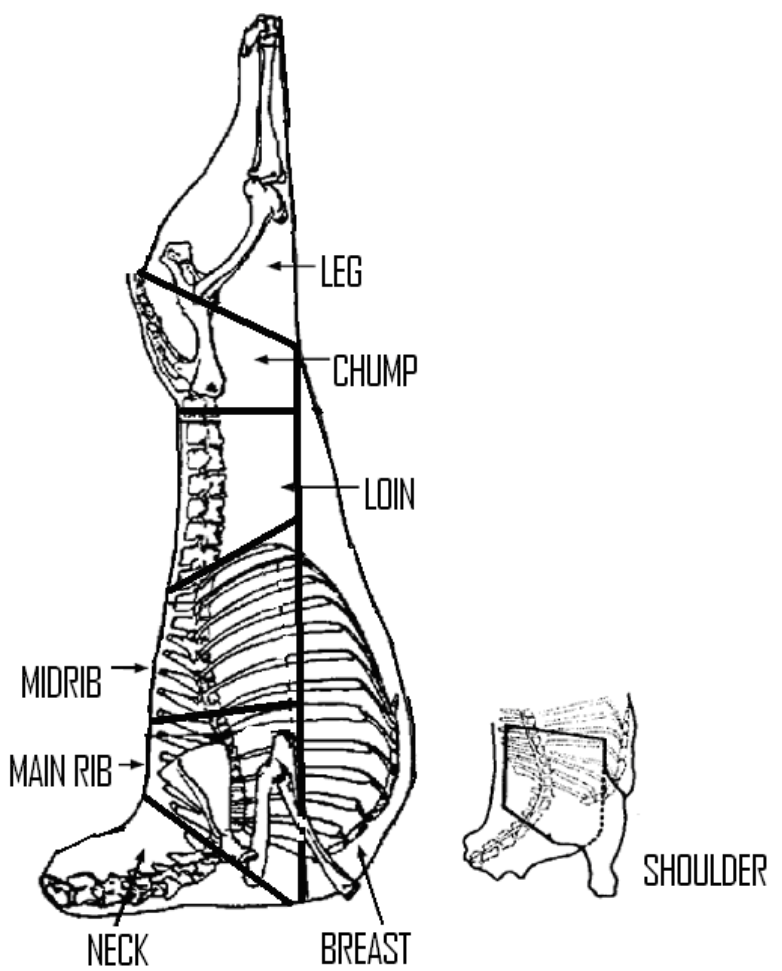

Figure 1. Carcass joints (modified from Calheiros and Neves, 1968). 
Table 1. Least-squares means of killing out characteristics of goat and sheep from traditional system

\begin{tabular}{|c|c|c|c|c|}
\hline \multirow{2}{*}{ Variable } & \multicolumn{2}{|c|}{ Species } & \multirow{2}{*}{ SEM } & \multirow[b]{2}{*}{$\mathrm{p}$} \\
\hline & Sheep & Goat & & \\
\hline \multicolumn{5}{|l|}{ Weights (kg) } \\
\hline Slaughter live BW & $22.29^{\mathrm{a}}$ & $20.50^{\mathrm{b}}$ & 0.55 & $*$ \\
\hline Empty body weight (EBW) & $20.17^{\mathrm{a}}$ & $18.67^{\mathrm{b}}$ & 0.51 & $*$ \\
\hline Hot carcass weight $(\mathrm{HCW})$ & 9.43 & 9.68 & 0.30 & NS \\
\hline Cold carcass weight & 9.06 & 9.27 & 0.29 & NS \\
\hline Chilling loss $(\%)$ & 3.92 & 4.19 & 0.41 & NS \\
\hline \multicolumn{5}{|l|}{ Dressing percentages (\%) } \\
\hline $\mathrm{HCW} \times 100 / \mathrm{BW}$ & $42.31^{\mathrm{b}}$ & $47.15^{\mathrm{a}}$ & 0.65 & $* * *$ \\
\hline $\mathrm{HCW} \times 100 / \mathrm{EBW}$ & $46.75^{\mathrm{b}}$ & $51.79^{\mathrm{a}}$ & 0.65 & $* * *$ \\
\hline
\end{tabular}

$\overline{\mathrm{a}, \mathrm{b}}$ The means with different letters in the same row differ significantly $(\mathrm{p}<0.05)$.

$\mathrm{SEM}=$ Standard error of the mean; $\mathrm{p}=$ Level of significance; $\mathrm{p}>0.05$ (N.S); $\mathrm{p}<0.05(*) ; \mathrm{p}<0.01(* *) ; \mathrm{p}<0.001(* * *) ; \mathrm{NS}=$ Not significant.

\section{RESULTS AND DISCUSSION}

\section{Slaughter characteristics}

The slaughter live BW, empty body weight (EBW), hot carcass weight $(\mathrm{HCW})$, cold carcass weight $(\mathrm{CCW})$ and dressing percentages of sheep and goats are presented in Table 1. Sheep had greater $(\mathrm{p}<0.05)$ slaughter live BW and EBW $(\mathrm{p}<0.05)$ than goats. Dressing percentages were greater $(p<0.001)$ in goats than sheep when expressed both as percent slaughter live BW (47.15\% vs $42.31 \%)$ and EBW $(51.79 \%$ vs $46.75 \%)$. Other studies have reported different values of dressing percentages between goats and sheep. Naude and Hofmeyr (1981) reported greater dressing percentages in Boer goats than sheep, whereas Riley et al. (1989) and Sen et al. (2004) reported lower dressing percentage for goats than sheep. Sen et al. (2004) showed that when dressing yield was expressed in terms of EBW, dressing percentage was not significant between the two species. Santos et al. (2008) when comparing carcasses and meat quality of Portuguese native goat and sheep breeds, found lambs to have greater dressing percentage than goat kids.

Gut contents contributed partly to the differences in dressing percentages (Table 2). The proportion of GI tract content to the slaughter live BW was greater $(\mathrm{p}<0.05)$ in sheep than goats. These findings further indicate that lower dressing proportion of sheep could also be due to increased weight of non-carcass components (Table 2). Greater weights of non-carcass components and gut fill are known to reduce dressing percentage. Dhanda et al. (1999) reported significant differences between various goat breeds for dressing percentage based on full body weight and attributed these differences to variations in weight of GI tract contents. Moreover, breed differences in dressing percentage are also attributed to the degree of gut fill at slaughter (Kadim et al., 2003). The current findings are similar to that of Titi et al. (2008) that showed increased weight of non-carcass, especially the digestive tract lead to a decreased dressing proportion.

The chilling loss was generally lower for sheep carcasses than goats (3.92\% vs $4.19 \%)$ as shown in Table 1. The reason could be due to differences in fat coverage, as

Table 2. Least-squares means of carcass and non-carcass component yields of goat and sheep

\begin{tabular}{|c|c|c|c|c|c|c|c|c|}
\hline \multirow{2}{*}{ Variable } & \multicolumn{2}{|c|}{ Species $(\mathrm{kg})$} & \multirow{2}{*}{ SEM } & \multirow{2}{*}{$\mathrm{p}$} & \multicolumn{2}{|c|}{ Species $(\%)$} & \multirow{2}{*}{ SEM } & \multirow{2}{*}{$\mathrm{p}$} \\
\hline & Sheep & Goat & & & Sheep & Goat & & \\
\hline GIT (Full, \% BW) & $3.53^{\mathrm{a}}$ & $3.09^{\mathrm{b}}$ & 0.10 & $* *$ & 15.84 & 15.10 & 0.27 & NS \\
\hline GIT (Fill, \% BW) & $1.45^{\mathrm{a}}$ & $1.00^{\mathrm{b}}$ & 0.11 & $* *$ & $6.46^{\mathrm{a}}$ & $4.92^{\mathrm{b}}$ & 0.46 & $*$ \\
\hline GIT (Empty) & 2.08 & 2.09 & 0.08 & NS & 10.36 & 11.17 & 0.34 & NS \\
\hline Head & $1.59^{\mathrm{a}}$ & $1.27^{\mathrm{b}}$ & 0.04 & $* * *$ & $7.90^{\mathrm{a}}$ & $6.83^{\mathrm{b}}$ & 0.13 & $* * *$ \\
\hline Skin & $1.66^{\mathrm{a}}$ & $1.39^{\mathrm{b}}$ & 0.05 & $* * *$ & $8.23^{\mathrm{a}}$ & $7.44^{\mathrm{b}}$ & 0.17 & $* *$ \\
\hline Feet & 0.52 & 0.56 & 0.02 & NS & $2.61^{\mathrm{b}}$ & $3.02^{\mathrm{a}}$ & 0.09 & $* *$ \\
\hline Internal organs & 0.94 & 0.97 & 0.03 & NS & $4.70^{\mathrm{b}}$ & $5.24^{\mathrm{a}}$ & 0.15 & $*$ \\
\hline Kidneys & 0.07 & 0.08 & 0.01 & NS & 0.35 & 0.44 & 0.03 & NS \\
\hline Internal fat & 0.07 & 0.11 & 0.03 & NS & 0.36 & 0.59 & 0.12 & NS \\
\hline Testicles & 0.23 & 0.19 & 0.02 & NS & 1.16 & 1.02 & 0.10 & NS \\
\hline Tail & $0.59^{\mathrm{a}}$ & $0.02^{\mathrm{b}}$ & 0.04 & $* * *$ & $2.91^{\mathrm{a}}$ & $0.10^{\mathrm{b}}$ & 0.18 & $* * *$ \\
\hline Total non-carcass & $7.76^{\mathrm{a}}$ & $6.68^{\mathrm{b}}$ & 0.17 & $* * *$ & $38.58^{\mathrm{a}}$ & $35.84^{\mathrm{b}}$ & 0.54 & $* * *$ \\
\hline
\end{tabular}

$\overline{\mathrm{a}, \mathrm{b}}$ The means with different letters in the same row differ significantly $(\mathrm{p}<0.05)$.

$\mathrm{SEM}=$ Standard error of the mean; GIT $=$ Gastrointestinal tract;

$\mathrm{p}=$ Level of significance; $\mathrm{p}>0.05(\mathrm{NS}) ; \mathrm{p}<0.05(*) ; \mathrm{p}<0.01(* *) ; \mathrm{p}<0.001(* * *) ; \mathrm{NS}=$ Not significant. 
sheep had slightly greater fat cover than goat carcasses and this could have prevented carcasses from losing weight emanating from evaporation. Furthermore, subcutaneous fat in this study was spread more evenly in sheep carcass. The present observations are also in agreement with those of Gaili and Ali (1985) and Colomer-Rocher et al. (1992). The non-carcass components, such as head and skin were significantly heavier in sheep than goats whereas the feet and internal organs were heavier in goats than sheep (Table 2 ). The difference in skin weight between species is partly ascribed to more hair weight in sheep in agreement with the observations made by Mahgoub and Lodge (1998) when comparing Omani sheep and goats and Sen et al. (2004) with Indian sheep and goats. The weight and percentages of feet, internal organs, kidneys, internal fat and testicles did not differ significantly between the two species except for the percentage of feet $(p<0.01)$ and internal organs $(p<0.05)$ when expressed as proportion of EBW. Other workers (Hadjipanayiotou and Koumas, 1994; El Khidir et al., 1998; Mahgoub and Lodge, 1998) have reported differences between sheep and goats in body fat. The authors showed that goats tend to deposit most of their fat internally, whereas in sheep more fat is deposited in the carcass surface. In this study, therefore sheep exhibited greater total non-carcass components than goats.

\section{Total carcass physical composition}

Least squares means of carcass compositions of sheep and goats carcasses are shown in Table 3. The weight of muscle was slightly greater but that of fat was lower $(\mathrm{p}<0.01)$ in goat than sheep carcasses. Sheep carcasses had proportionally lower muscle and edible yield (muscle plus fat) to bone ratio and considerably greater $(\mathrm{p}<0.001)$ dissectible fat than goat carcasses; a finding which is in line with earlier studies (Gaili and Ali, 1985). The observed differences for carcass tissue compositions is a reflection of species differences, a conclusion in agreement with other reports that indicated goat carcass are generally leaner than sheep (Naude and Hofmeyr, 1981; Tshabalala et al., 2003; Sen et al., 2004). In addition, the greater muscle content, lower dissectible fat and bone in goat carcasses compared with sheep are in agreement with those obtained by Santos et al. (2008) with Portuguese native goat and sheep breeds and El Khidir et al. (1998) with Sudanese desert goats. El Khidir et al. (1998) reported higher muscle to bone ratio in the desert goats, a finding in conformity with the present study. In agreement with this study and an intensive literature review by Santos et al. (2008) on differences on carcass composition between sheep and goats concluded that sheep generally tend to have more carcass fat than goats.

\section{Standard joints and composition of carcass joints}

Least squares means of weight of joints in sheep and goats in absolute values $(\mathrm{kg})$ and percentage (\%) of left half carcass weight are shown in Table 4 . The joints in the study are primal cuts, which are being promoted in Tanzania for easiness of carcass marketing and correspond closely to the units that consumers prefer to buy from a retail butcher (Luziga, 2005; Mwilawa et al., 2007). These primal cuts can further be split into smaller retail units depending on the market where the meat is going to be sold. The effects of species on the proportion of standard joints tended to be small. The proportion of shoulder joint in sheep carcasses was lower $(p<0.001)$ than goats $(18.89 \%$ vs $22.68 \%)$. However, the proportion of chump and main rib were

Table 3. Least squares means of carcass compositions of left half carcass from sheep and goats

\begin{tabular}{|c|c|c|c|c|}
\hline \multirow{2}{*}{ Variable } & \multicolumn{2}{|c|}{ Species } & \multirow{2}{*}{ SEM } & \multirow{2}{*}{$\mathrm{p}$} \\
\hline & Sheep & Goat & & \\
\hline Left cold carcass weight (LCCW) & 4.42 & 4.54 & 0.15 & NS \\
\hline \multicolumn{5}{|l|}{ Weights of tissues (kg) } \\
\hline Muscle & 2.93 & 3.25 & 0.11 & NS \\
\hline Dissectible fat & $0.33^{\mathrm{a}}$ & $0.16^{\mathrm{b}}$ & 0.03 & $* *$ \\
\hline Bone & 1.16 & 1.13 & 0.04 & NS \\
\hline Muscle and fat & 3.26 & 3.41 & 0.12 & NS \\
\hline \multicolumn{5}{|l|}{ Weights of tissues (\% LCCW) } \\
\hline Muscle & $66.18^{\mathrm{b}}$ & $71.64^{\mathrm{a}}$ & 0.68 & $* * *$ \\
\hline Dissectible fat & $7.41^{\mathrm{a}}$ & $3.44^{\mathrm{b}}$ & 0.74 & $* * *$ \\
\hline Bone & 26.41 & 24.92 & 0.58 & NS \\
\hline Muscle and dissectible fat & 73.59 & 75.08 & 0.58 & NS \\
\hline \multicolumn{5}{|l|}{ Tissue ratio } \\
\hline Muscle to bone & $2.53^{\mathrm{b}}$ & $2.90^{\mathrm{a}}$ & 0.07 & $* *$ \\
\hline Muscle and dissectible fat: Bone & 2.82 & 3.04 & 0.09 & NS \\
\hline
\end{tabular}

${ }^{\mathrm{a}, \mathrm{b}}$ The means with different letters in the same row differ significantly $(\mathrm{p}<0.05)$.

$\mathrm{SEM}=$ Standard error of the mean; $\mathrm{p}=$ Level of significance; $\mathrm{p}>0.05$ (NS); $<<0.05(*) ; \mathrm{p}<0.01(* *) ; \mathrm{p}<0.001(* * *)$; NS = Not significant. 
Table 4. Least squares means of weight of joints in sheep and goats in absolute values $(\mathrm{kg})$ and percentage $(\%)$ of left half carcass weight

\begin{tabular}{|c|c|c|c|c|c|c|c|c|}
\hline \multirow{2}{*}{ Carcass joint } & \multicolumn{2}{|c|}{ Wt of joint $(\mathrm{kg})$} & \multirow{2}{*}{ SEM } & \multirow{2}{*}{$\mathrm{p}$} & \multicolumn{2}{|c|}{ Wt of joint (\%) } & \multirow{2}{*}{ SEM } & \multirow{2}{*}{$\mathrm{p}$} \\
\hline & Sheep & Goat & & & Sheep & Goat & & \\
\hline Left carcass & 4.42 & 4.54 & 0.15 & NS & 100 & 100 & 1 & \\
\hline Leg & 1.17 & 1.16 & 0.02 & NS & 26.51 & 25.72 & 0.32 & NS \\
\hline Chump & 0.35 & 0.30 & 0.02 & NS & $7.91^{\mathrm{a}}$ & $6.76^{\mathrm{b}}$ & 0.32 & $*$ \\
\hline Loin & 0.43 & 0.41 & 0.02 & NS & 9.77 & 9.07 & 0.32 & NS \\
\hline Midrib & 0.42 & 0.40 & 0.02 & NS & 9.48 & 8.84 & 0.32 & NS \\
\hline Main rib & 0.36 & 0.32 & 0.02 & NS & $8.12^{\mathrm{a}}$ & $7.07^{\mathrm{b}}$ & 0.32 & $*$ \\
\hline Shoulder & $0.83^{\mathrm{b}}$ & $1.03^{\mathrm{a}}$ & 0.02 & $* * *$ & $18.89^{\mathrm{b}}$ & $22.68^{\mathrm{a}}$ & 0.32 & $* * *$ \\
\hline Breast & 0.38 & 0.41 & 0.02 & NS & 8.48 & 8.90 & 0.32 & NS \\
\hline Neck & 0.48 & 0.50 & 0.02 & NS & 10.85 & 10.96 & 0.32 & NS \\
\hline
\end{tabular}

${ }^{\mathrm{a}, \mathrm{b}}$ The means with different letters in the same row differ significantly $(\mathrm{p}<0.05)$.

$\mathrm{SEM}=$ Standard error of the mean; Wt = Weight; $\mathrm{p}=$ Level of significance; $\mathrm{p}>0.05(\mathrm{NS}) ; \mathrm{p}<0.05(*) ; \mathrm{p}<0.01(* *) ; \mathrm{p}<0.001(* * *) ; \mathrm{NS}=\mathrm{Not}$ significant.

greater in sheep than goat carcasses (Table 4). Sen et al. (2004) have reported similar observations whereby the neck and shoulder was heavier $(\mathrm{p}<0.01)$ in goats than sheep. The findings are also in line with the observations by Mahgoub and Lodge (1998) and Cameron et al. (2001) who reported that male goats deposit relatively more weight in the forequarters than in the hindquarters.

In addition, other workers too reported higher values in the anterior rib and shoulder joint of goats compared with those of sheep (Santos et al., 2008). The observed species differences in joint proportions in the shoulder and slight difference in the neck and breast could be due to differences on the posture adopted by the two species while grazing. It has been noted that, goats in semiarid and arid regions mainly subsist on browsing shrubs and trees, requiring erect and extended neck posture with a two legs stance (Bhatta et al., 2001). This habit could have partly contributed to the observed differences in the joints related to forequarters. The proportion of chump from sheep carcasses was higher $(\mathrm{p}<0.05)$ than goat carcasses, which could be due to differences in fatty tissue deposition. Consequently, comparisons of absolute values with those from other studies are difficult in relation to commercial carcass joints due to variability in method and between workers in jointing the primal cuts. In the present study, however attempts were taken to use clearly anatomical boundaries.

Least squares means of muscles in joints in sheep and goats in absolute weight and weight as percent of total half carcass muscle weight are shown in Table 5. The leg and main rib of sheep joints contained significantly greater proportion of muscle ( $28.83 \%$ vs $27.08 \%, 7.62 \%$ vs $6.36 \%$ ) and lower proportion in the shoulder joints $(20.28 \%$ vs $23.56 \%$ ) than goats. In sheep carcasses, proportion of muscle relative to total muscle was greater in leg joint followed by shoulder, neck, loin, midrib, main rib, chump and breast in decreasing order.

The greater proportion of muscle in leg and main rib joints for sheep are contrary to the previous results reported by Santos et al. (2008) where sheep had lower proportion than goats. However, greater $(\mathrm{p}<0.001)$ proportions of muscle in the shoulder joints and total muscle in the carcass of goats compared with sheep are in agreement with the previous reports (Sen et al., 2004; Santos et al., 2008). The distribution of fat in each individual joint of sheep and goats relative to total fat is presented in Table 6 where a greater fat content in sheep agrees with the results obtained

Table 5. Least squares means of muscles in joints in sheep and goats in weight $(\mathrm{kg})$ and percentage $(\%)$ of total half carcass muscle weight

\begin{tabular}{|c|c|c|c|c|c|c|c|c|}
\hline \multirow{2}{*}{ Carcass joint } & \multicolumn{2}{|c|}{ Muscle wt (kg) } & \multirow{2}{*}{ SEM } & \multirow[b]{2}{*}{$\mathrm{p}$} & \multicolumn{2}{|c|}{ Muscle wt (\%) } & \multirow{2}{*}{ SEM } & \multirow{2}{*}{$\mathrm{p}$} \\
\hline & Sheep & Goat & & & Sheep & Goat & & \\
\hline Carcass muscle $^{c}$ & 2.93 & 3.25 & 0.11 & NS & $66.18^{\mathrm{b}}$ & $71.64^{\mathrm{a}}$ & 0.68 & $* * *$ \\
\hline Leg & 0.84 & 0.88 & 0.02 & NS & $28.83^{\mathrm{a}}$ & $27.08^{b}$ & 0.33 & $* * *$ \\
\hline Chump & 0.21 & 0.22 & 0.02 & NS & 7.24 & 6.91 & 0.33 & NS \\
\hline Loin & 0.29 & 0.29 & 0.02 & NS & 9.93 & 9.00 & 0.33 & NS \\
\hline Midrib & 0.26 & 0.27 & 0.02 & NS & 8.78 & 8.24 & 0.33 & NS \\
\hline Main rib & 0.22 & 0.21 & 0.02 & NS & $7.62^{\mathrm{a}}$ & $6.36^{\mathrm{b}}$ & 0.33 & $* *$ \\
\hline Shoulder & $0.59^{\mathrm{b}}$ & $0.76^{\mathrm{a}}$ & 0.02 & $* * *$ & $20.28^{\mathrm{b}}$ & $23.56^{\mathrm{a}}$ & 0.33 & $* * *$ \\
\hline Breast & $0.21^{\mathrm{b}}$ & $0.27^{\mathrm{a}}$ & 0.02 & $*$ & 7.16 & 8.07 & 0.33 & NS \\
\hline Neck & $0.30^{\mathrm{b}}$ & $0.35^{\mathrm{a}}$ & 0.02 & $*$ & 10.16 & 10.79 & 0.33 & NS \\
\hline
\end{tabular}

$\overline{\mathrm{a}, \mathrm{b}}$ The means with different letters in the same row differ significantly $(\mathrm{p}<0.05) .{ }^{\mathrm{c}}$ Muscle weight as \% of total carcass weight.

$\mathrm{SEM}=$ Standard error of the mean; $w \mathrm{t}=$ Weight; $\mathrm{p}=$ Level of significance; $\mathrm{p}>0.05(\mathrm{NS}) ; \mathrm{p}<0.05(*) ; \mathrm{p}<0.01(* *) ; \mathrm{p}<0.001(* * *) ; \mathrm{NS}=\mathrm{Not}$ significant. 
Table 6. Least square means of fat in joints in sheep and goats in absolute values $(\mathrm{kg})$ and percentage (\%) of half carcass fat weight

\begin{tabular}{|c|c|c|c|c|c|c|c|c|}
\hline \multirow{2}{*}{ Carcass joint } & \multicolumn{2}{|c|}{ Wt of fat $(\mathrm{kg})$} & \multirow{2}{*}{ SEM } & \multirow{2}{*}{$\mathrm{p}$} & \multicolumn{2}{|c|}{ Wt of fat, $\%$} & \multirow{2}{*}{ SEM } & \multirow{2}{*}{$\mathrm{p}$} \\
\hline & Sheep & Goat & & & Sheep & Goat & & \\
\hline Carcass fat $^{\mathrm{c}}$ & $0.33^{\mathrm{a}}$ & $0.16^{\mathrm{b}}$ & 0.03 & $* *$ & 7.41 & 3.44 & 0.74 & $* * *$ \\
\hline Leg & $0.06^{\mathrm{a}}$ & $0.03^{b}$ & 0.01 & $* * *$ & 18.64 & 15.39 & 2.52 & NS \\
\hline Chump & $0.06^{\mathrm{a}}$ & $0.01^{\mathrm{b}}$ & 0.01 & $* * *$ & $19.34^{\mathrm{a}}$ & $8.74^{b}$ & 2.52 & $* *$ \\
\hline Loin & $0.04^{\mathrm{a}}$ & $0.02^{\mathrm{b}}$ & 0.01 & $*$ & 11.01 & 10.52 & 2.52 & NS \\
\hline Midrib & 0.02 & 0.01 & 0.01 & NS & 6.56 & 8.58 & 2.52 & NS \\
\hline Main rib & 0.01 & 0.01 & 0.01 & NS & 3.72 & 5.67 & 2.52 & NS \\
\hline Shoulder & 0.03 & 0.03 & 0.01 & NS & 7.10 & 10.95 & 2.52 & NS \\
\hline Breast & $0.08^{\mathrm{a}}$ & $0.04^{\mathrm{b}}$ & 0.01 & $* * *$ & $24.44^{\mathrm{b}}$ & $32.09^{\mathrm{a}}$ & 2.52 & $*$ \\
\hline Neck & $0.03^{\mathrm{a}}$ & $0.01^{\mathrm{b}}$ & 0.01 & $*$ & 9.19 & 8.06 & 2.52 & NS \\
\hline
\end{tabular}

${ }^{\mathrm{a}, \mathrm{b}}$ The means with different letters in the same row differ significantly $(\mathrm{p}<0.05) .{ }^{\mathrm{c}}$ Carcass fat as $\%$ of total carcass weight.

SEM = Standard error of the mean; Wt = Weight $; \mathrm{p}=$ Level of significance; $\mathrm{p}>0.05(\mathrm{NS}) ; \mathrm{p}<0.05(*) ; \mathrm{p}<0.01(* *) ; \mathrm{p}<0.001(* * *) ; \mathrm{NS}=\mathrm{Not}$ significant.

Table 7. Least squares means of edible joint yields in sheep and goats in absolute values $(\mathrm{kg})$ and percentage (\%) of half carcass edible yield

\begin{tabular}{|c|c|c|c|c|c|c|c|c|}
\hline \multirow{2}{*}{ Carcass joint } & \multicolumn{2}{|c|}{ Edible yd (kg) } & \multirow{2}{*}{ SEM } & \multirow{2}{*}{$\mathrm{p}$} & \multicolumn{2}{|c|}{ Percent yd (\%) } & \multirow{2}{*}{ SEM } & \multirow{2}{*}{$\mathrm{p}$} \\
\hline & Sheep & Goat & & & Sheep & Goat & & \\
\hline Carcass yield $^{c}$ & 3.26 & 3.41 & 0.12 & NS & 73.59 & 75.08 & 0.58 & NS \\
\hline Leg & 0.90 & 0.91 & 0.02 & NS & $27.85^{\mathrm{a}}$ & $26.65^{\mathrm{b}}$ & 0.35 & $*$ \\
\hline Chump & 0.27 & 0.24 & 0.02 & NS & $8.38^{\mathrm{a}}$ & $7.03^{\mathrm{b}}$ & 0.35 & $* *$ \\
\hline Loin & 0.33 & 0.31 & 0.02 & NS & 10.10 & 9.16 & 0.35 & NS \\
\hline Midrib & 0.28 & 0.28 & 0.02 & NS & 8.55 & 8.18 & 0.35 & NS \\
\hline Main rib & 0.24 & 0.22 & 0.02 & NS & 7.24 & 6.28 & 0.35 & NS \\
\hline Shoulder & $0.62^{\mathrm{b}}$ & $0.79^{\mathrm{a}}$ & 0.02 & $* * *$ & $19.04^{\mathrm{b}}$ & $23.26^{\mathrm{a}}$ & 0.35 & $* * *$ \\
\hline Breast & 0.29 & 0.30 & 0.02 & NS & 8.79 & 8.80 & 0.35 & NS \\
\hline Neck & 0.33 & 0.36 & 0.02 & NS & 10.05 & 10.64 & 0.35 & NS \\
\hline
\end{tabular}

$\overline{\mathrm{a}, \mathrm{b}}$ The means with different letters in the same row differ significantly $(\mathrm{p}<0.05) .{ }^{\mathrm{c}}$ Carcass edible joint yield as $\%$ total carcass weight. $\mathrm{SEM}=$ Standard error of the mean; $y d=$ Yield; $\mathrm{p}=$ Level of significance; $\mathrm{p}>0.05(\mathrm{NS}) ; \mathrm{p}<0.05(*) ; \mathrm{p}<0.01(* *) ; \mathrm{p}<0.001(* * *)$; NS $=$ Not significant.

by Sen et al. (2004) in carcass cuts. Despite sheep having greater fat proportions in most joints, the weight of the proportions of muscle was significantly greater in the shoulder, neck and breast of goat carcasses resulting into greater proportions of edible yields (Table 7).

The current observations in this study are in line with the results obtained by Tshabalala et al. (2003) who found that although Damara and Dorper sheep contained a greater proportion of fat in most cuts, the Boer goat had a significantly greater proportion of muscle in the neck. Data on bone components in each individual joint expressed on basis of total carcass bones of sheep and goats are presented in Table 8. The shoulder and breast joints of sheep carcasses had significantly lower proportion of bones $(18.58 \%$ vs

Table 8. Least squares means of weight of bone in joints in goats and sheep in absolute values $(\mathrm{kg})$ and percentage $(\%)$ of half carcass bone weight

\begin{tabular}{|c|c|c|c|c|c|c|c|c|}
\hline \multirow{2}{*}{ Carcass joint } & \multicolumn{2}{|c|}{ Bone wt (kg) } & \multirow{2}{*}{ SEM } & \multirow{2}{*}{$\mathrm{p}$} & \multicolumn{2}{|c|}{ Bone wt (\%) } & \multirow{2}{*}{ SEM } & \multirow{2}{*}{$\mathrm{p}$} \\
\hline & Sheep & Goat & & & Sheep & Goat & & \\
\hline Carcass bone $^{\mathrm{c}}$ & 1.16 & 1.13 & 0.04 & NS & 26.41 & 24.92 & 0.58 & NS \\
\hline Leg & 0.26 & 0.26 & 0.01 & NS & 22.93 & 22.95 & 0.56 & NS \\
\hline Chump & 0.08 & 0.07 & 0.01 & NS & 6.58 & 5.91 & 0.56 & NS \\
\hline Loin & 0.10 & 0.10 & 0.01 & NS & 8.85 & 8.70 & 0.56 & NS \\
\hline Midrib & 0.14 & 0.12 & 0.01 & NS & 12.11 & 10.80 & 0.56 & NS \\
\hline Main rib & 0.12 & 0.11 & 0.01 & NS & 10.36 & 9.46 & 0.56 & NS \\
\hline Shoulder & 0.22 & 0.23 & 0.01 & NS & $18.58^{\mathrm{b}}$ & $20.96^{\mathrm{a}}$ & 0.56 & $* *$ \\
\hline Breast & 0.09 & 0.10 & 0.01 & NS & $7.65^{\mathrm{b}}$ & $9.22^{\mathrm{a}}$ & 0.56 & $*$ \\
\hline Neck & 0.15 & 0.14 & 0.01 & NS & 12.95 & 12.01 & 0.56 & NS \\
\hline
\end{tabular}

${ }^{\mathrm{a}, \mathrm{b}}$ The means with different letters in the same row differ significantly $(\mathrm{p}<0.05) .{ }^{\mathrm{c}}$ Carcass bone as \% of total carcass weight. $\mathrm{SEM}=$ Standard error of the mean; $w \mathrm{t}=$ Weight; $\mathrm{p}=$ Level of significance; $\mathrm{p}>0.05(\mathrm{NS}) ; \mathrm{p}<0.05(*) ; \mathrm{p}<0.01(* *) ; \mathrm{p}<0.001(* * *) ; \mathrm{NS}=\mathrm{Not}$ significant. 
Table 9. Yield of carcass joints in sheep and goats as judged by muscle to bone and edible yield to bone ratios of half carcass

\begin{tabular}{|c|c|c|c|c|c|c|c|c|}
\hline \multirow{2}{*}{ Carcass joint } & \multicolumn{2}{|c|}{ MB ratio } & \multirow{2}{*}{ SEM } & \multirow{2}{*}{$\mathrm{p}$} & \multicolumn{2}{|c|}{ EB ratio } & \multirow{2}{*}{ SEM } & \multirow{2}{*}{$\mathrm{p}$} \\
\hline & Sheep & Goat & & & Sheep & Goat & & \\
\hline Carcass $^{c}$ & $2.53^{\mathrm{b}}$ & $2.90^{\mathrm{a}}$ & 0.07 & $* *$ & 2.82 & 3.04 & 0.09 & $\mathrm{NS}$ \\
\hline Leg & 3.20 & 3.44 & 0.29 & NS & 3.44 & 3.56 & 0.40 & NS \\
\hline Chump & $2.98^{\mathrm{b}}$ & $3.79^{\mathrm{a}}$ & 0.29 & $*$ & 3.90 & 4.14 & 0.40 & NS \\
\hline Loin & 3.06 & 3.55 & 0.29 & NS & 3.50 & 3.82 & 0.40 & NS \\
\hline Midrib & 1.85 & 2.29 & 0.29 & NS & 2.00 & 2.38 & 0.40 & NS \\
\hline Main rib & 2.61 & 1.99 & 0.29 & NS & 3.07 & 2.07 & 0.40 & NS \\
\hline Shoulder & 2.77 & 3.27 & 0.29 & NS & 2.89 & 3.39 & 0.40 & NS \\
\hline Breast & 2.40 & 2.59 & 0.29 & NS & 3.28 & 2.97 & 0.40 & NS \\
\hline Neck & 2.09 & 2.66 & 0.29 & NS & 2.31 & 2.76 & 0.40 & NS \\
\hline
\end{tabular}

${ }^{\mathrm{a}, \mathrm{b}}$ The means with different letters in the same row differ significantly $(\mathrm{p}<0.05) .{ }^{\mathrm{c}}$ Muscle to bone and edible yield to bone ratios of whole carcass. $\mathrm{SEM}=$ Standard error of the mean; $\mathrm{MB}=$ Muscle to bone; $\mathrm{EB}=$ Edible yield;

$\mathrm{p}=$ Level of significance; $\mathrm{p}>0.05(\mathrm{NS}) ; \mathrm{p}<0.05(*) ; \mathrm{p}<0.01(* *) ; \mathrm{p}<0.001(* * *) ; \mathrm{NS}=$ Not significant.

$20.96 \%$ and $7.65 \%$ vs $9.22 \%$ ) than goat carcasses. Observation from the current study shows that, the difference in bone proportion between sheep and goats in most of joints studied were not significant. The observed similarities in the proportion of bones in most joints of these species could be explained by the early maturing nature of bone tissue (Berg and Butterfield, 1976; Kerth et al., 2007). Bone matures early in lifetime such that its turnover rate is slower than that of fat and muscles latter in life (Atti et al., 2006).

There were no species differences in muscle to bone and edible yield to bone ratios in most of the joints studied (Table 9). Although not significant, goats had superior edible yield to bone ratios in leg, chump, loin and midrib, and shoulder joints and inferior edible yield to bone ratios in main rib and breast joints. The findings may have important implications in marketing of meat from sheep and goats. The results suggest that some joints, which have favourable superior edible yield to bone ratios such as leg, chump, loin, midrib and breast in both sheep and goats should be sold at a greater price than other joints. Consumers in the niche markets are expected to pay more for purchasing such joints although further studies on the willingness of consumers to pay for producing such tender joints are needed.

\section{CONCLUSIONS}

It is concluded that there are differences in carcass yield, carcass composition and that of joints between sheep and goat from the traditional system. Goats should be valued as a different species compared to sheep and that marketing strategies of the carcasses from the two species may be different. However, due to the relatively small sample size used in the current study, further research would be needed to develop recommendations for commercial practice.

\section{ACKNOWLEDGEMENTS}

The financial support from ENRECA IGMAFU Project 841 funded by DANIDA at the Department of Animal Science and Production of Sokoine University of Agriculture is gratefully acknowledged. Thanks are also due to the department of Meat Processing Technology of Dodoma Regional Vocational Education Training and Services Centre for permission to use its facilities during the study.

\section{REFERENCES}

Abegaz, S. and K. Awgichew. 2009. Estimation of weight and age of sheep and goats. In: ESGPIP (Ethiopia Sheep and Goat Productivity Improvement Program) Technical Bulletin No.23. (Ed. Alemu Yami, T. A. Gipson and R. C. Merkel).

Atti, N., H. Rouissi and M. Mahouachi. 2006. The effect of spineless cactus (Opuntia ficus-indica f. inermis) supplementation on growth, carcass, meat quality and fatty acid composition of male goat kids. Meat Sci. 73:229-235.

Babiker, S. A., I. A. El Khider and S. A. Shafie. 1990. Chemical composition and quality attributes of goat meat and lamb. Meat Sci. 28:273-277.

Berg, R. T. and R. M. Butterfield. 1976. New Concepts of Cattle Growth, Sydney University Press, Sydney, Australia, p. 240.

Bhatta, R., S. K. Sankhyan, A. K. Shinde and D. L. Verma. 2001. Seasonal changes in diet selectivity and grazing behaviour of goats on semiarid rangeland. Indian J. Anim. Sci. 71:62-65.

Bonvillani, A., F. Peña, G. de Gea, G. Gómez, A. Petryna and J. Perea. 2010. Carcass characteristics of Criollo Cordobés kid goats under an extensive management system: Effects of gender and live weight at slaughter. Meat Sci. 86:651-659.

Calheiros, F. and A. Neves. 1968. Rendimentos ponderais no Borrego Merino Precoce. Carcaça e $5^{\circ}$ quarto. Separata Boletim Pecuário XXXVI:117-126. (In Portuguese)

Cameron, M. R., J. Luo, T. Sahlu, S. P. Hart, S. W. Coleman and A. L. Goetsch. 2001. Growth and slaughter traits of Boer $\times$ Spanish, Boer $\times$ Angora and Spanish goats consuming a concentratebased diet. J. Anim Sci. 79:1423-1430. 
Colomer-Rocher, F., A. H. Kirton, G. J. K. Mercer and D. M. Duganzich. 1992. Carcass composition of New Zealand Saanen goats slaughtered at different weights. Small Rumin. Res. 7:161-173.

Dhanda, J. S., D. G. Taylor, J. E. McCosker and P. J. Murray. 1999. The influence of goat genotype on the production of Capretto and Chevon carcasses. 1. Growth and carcass characteristics. Meat Sci. 52:355-361.

El Khidir, I. A., S. A. Babiker and S. A. Shafie. 1998. Comparative feedlot performance and carcass characteristics of Sudanese desert sheep and goats. Small Rumin. Res. 30:147-151.

Gaili, E. S. and A. E. Ali. 1985. Meat from Sudan desert sheep and goats. Part 2. Composition of the muscular and fatty tissues. Meat Sci. 13:229-236.

Hadjipanayiotou, M. and A. Koumas. 1994. Carcass characteristics of equally mature Chios lambs and Damascus kids. Small Rumin. Res. 13:71-77.

Hango, A., L. A. Mtenga, G. C. Kifaro, J. Safari, D. E. Mushi and V. R. M. Muhikambele. 2007. A study on growth performance and carcass characteristics of Small East African goats under different feeding regimes. Livest. Res. Rural Dev. Volume 19, Article \#130.

Kadim, I. T., O. Mahgoub, D. S. Al-Ajmi, R. S. Al-Maqbaly, N. M. Al-Saqri and A. Ritchie. 2003. An evaluation of the growth, carcass and meat quality characteristics of Omani goat breeds. Meat Sci. 66:203-210.

Kerth, C. R., K. W. Braden, R. Cox, L. K. Kerth and J. Rankins. 2007. Carcass, sensory, fat colour and consumer acceptance characteristics of Angus Cross steers finished on ryegrass (Lolium multiflorum) forage or on a high concentrate diet. Meat Sci. 75:324-331.

Lee, J. H., G. Kannan, K. R. Eega, B. Kouakou and W. R. Getz. 2008. Nutritional and quality characteristics of meat from goats and lambs finished under identical dietary regime. Small Rumin. Res.74:255-259.

Mahgoub, O. and G. A. Lodge. 1998. A comparative study on growth, body composition and carcass tissue distribution in Omani sheep and goats. J. Agric. Sci. (Camb.) 131:329-339.

Mahgoub, O. and C. D. Lu. 1998. Growth, body composition and carcass tissue distribution in goats of large and small sizes. Small Rumin. Res. 27:267-278.

Miller, M. F., M. A. Carr, C. B. Ramsey, K. L. Crockett and L. C. Hoover. 2001. Consumer thresholds for establishing the value of beef tenderness. J. Anim. Sci. 79:3062-3068.

Msanga, Y. N. 2009. Potential of meat industry in Tanzania. Ministry of Livestock Development and Fisheries, Tanzania.

Mushi, D. E. 2004. Studies on marketing of meat goats and carcass composition - a case study of Gairo auction markets. MSc. Dissertation, Sokoine University of Agriculture, Morogoro, Tanzania.
Mushi, D. E., J. Safari, L. A. Mtenga, G. C. Kifaro and L. O. Eik. 2009. Effects of concentrate levels on fattening performance, carcass and meat quality attributes of Small East Africanx Norwegian crossbred goats fed low quality grass hay. Livest. Sci. 124:148-155.

Mwilawa, A. J., A. E. Kimambo, L. A. Mtenga, J. Madsen, T. Hvelplund, M. Weisbjerg, G. H. Laswai, D. M. Mgheni and M. Christensen. 2007. Evaluation of breed and diet for carcass characteristics and meat quality of beef cattle. Proceedings of the 2nd TSAP/TVA Joint International Conference held at AICC from 29th November - 1st December 2007, Arusha, Tanzania.

Naude, R. T. and H. S. Hofmeyr. 1981. Meat production. In: Goat Production (Ed. C. Gall) (pp. 285-307). London: Academic press.

Owen, J. E., G. A. Norman, C. A. Philbrooks and N. S. D. Jones. 1978. Studies on the meat production characteristics of Botswana goats and sheep. III. Carcass tissue composition and distribution. Meat Sci. 2:59-74.

Riley, R. R., J. W. Savell, M. Shelton and G. C. Smith. 1989. Carcass and offal yields of sheep and goats as influenced by market class and breed. Small Rumin. Res. 2:265-272.

Safari, J. G., D. E. Mushi, L. A. Mtenga, G. C. Kifaro and L. O. Eik. 2009. Effects of concentrate supplementation on carcass and meat quality attributes of feedlot finished Small East African goats. Livest. Sci. 125:266-274.

Safari, J. G., D. E. Mushi, L. A. Mtenga, G. C. Kifaro and L. O. Eik. 2011. Growth, carcass yield and meat quality attributes of Red Maasai sheep fed wheat straw-based diets. Trop. Anim. Health Prod. 43:89-97.

Santos, V. A. C., S. R. Silva and J. M. T. Azevedo. 2008. Carcass composition and meat quality of equally mature kids and lambs. J. Anim. Sci. 86:1943-1950.

SAS. 2000. Statistical analysis system, User's Guide, Version 8.2. SAS Institute, INC Carry. NC, USA.

Sen, A. R., A. Santra and S. A. Karim. 2004. Carcass yield, composition and meat quality attributes of sheep and goat under semiarid conditions. Meat Sci. 66:757-763.

Titi, H. H., R. O. Dmour and A. Y. Abdullah. 2008. Growth performance and carcass characteristics of Awassi lambs and Shami goat kids fed yeast culture in their finishing diet. Anim. Feed Sci. Technol. 142:33-43.

Tshabalala, P. A., P. E. Strydom, E. C. Webb and H. L. De Kock. 2003. Meat quality of designated South African indigenous goat and sheep breeds. Meat Sci. 65:563-570.

Voges, K. L., C. L. Mason, J. C. Brooks, R. J. Delmore, D. B. Griffin and D. S. Hale. 2007. National beef tenderness survey 2006: Assessment of Warner-Bratzler shear and sensory panel ratings for beef from US retail and foodservice establishments. Meat Sci. 77:357-364. 